\title{
Biology of shallow marine ichnology: a modern perspective
}

\author{
Murray K. Gingras ${ }^{1, *}$, Shahin E. Dashtgard ${ }^{2}$, James A. MacEachern ${ }^{2}$, \\ S. George Pemberton ${ }^{1}$ \\ ${ }^{1}$ Department of Earth and Atmospheric Sciences, 1-26 Earth Science Building, University of Alberta, Edmonton, \\ Alberta T6G 2E3, Canada \\ ${ }^{2}$ Department of Earth Sciences, Simon Fraser University, Burnaby, British Columbia V5A 1S6, Canada
}

\begin{abstract}
This study considers the construction and functionality of biogenic structures made by marine, vermiform nemerteans, polychaetes and hemichordates; marine crustaceans; motile bivalves; motile echinoderms; and sponges and sea anemones. We report on a range of modern biogenic structures similar to several known ichnogenera. Vermiform animals dominantly occupy vertical burrows that range from simple through helical shafts to Y- and U-shapes. Horizontal traces made by worms range in form, but are dominated by branching and variably sinuous to meandering burrows. Crustaceans primarily excavate open burrow systems that possess a range of architectures that are similar to either Thalassinoides or Psilonichnus. Smaller crustaceans, such as amphipods, mix the sediment. Bivalve traces vary in form, but generally preserve evidence of vertically oriented filter or interface-deposit feeding from a stationary location, rapid vertical escape, or horizontal grazing. Echinoderms dominantly preserve body impressions and motility traces, such as Asteriacites. An important class of biogenic structure, Scolicia and Bichordites, are made by urchins. Finally, sea anemones can generate large, penetrative, conical biogenic structures. Large, open horizontal networks serve as domiciles and deposit-feeding structures for crustaceans, but with worms similar burrow types are used more for passive carnivory and establishing an interface-feeding network. We report that the trace fossil Gyrolithes potentially represents mechanical ramps for shrimp, but is used as a sediment holdfast when made by worms. Finally, Y-shaped burrows are used for filter feeding in shrimp, and interface-deposit feeding in worms. These examples emphasize that inferences of behavior in the rock record are interpretive.
\end{abstract}

KEY WORDS: Ichnology · Neoichnology $\cdot$ Traces $\cdot$ Crustacea $\cdot$ Vermiforms $\cdot$ Bivalves $\cdot$ Echinoderms · Anemones

Resale or republication not permitted without written consent of the publisher

\section{INTRODUCTION}

Ichnology is the study of trace fossils (or ichnofossils), which primarily constitute the fossilized trails and burrows of animals. Commonly, and inaccurately referred to as 'tracks and trails', these vestiges of animal activity reflect the behavior that animals employed in order to live, feed, move, or hide within their environments. Interpretation of the animal's behavior can lead to better interpretations of the depositional conditions, towards which ichnology is largely applied. Trace fossils are classified morphologically, and are assigned to ichnogenera and ichnospecies on that basis (see Bertling et al. 2006 for a complete review of ichnotaxonomy). As such, trace-fossil names are taxonomically independent of the animal that made them. Below we present several trace-fossil names. These are used so that this summary paper can be linked to the ichnological literature.

Although trace fossils may owe much of their resultant morphology to their tracemaker, this relationship is rarely stressed in the ichnological literature. This is mainly because a large range of tracemakers can generate the same traces if employing broadly similar 
behaviors to survive comparable environmental conditions (Ekdale et al. 1984). Nevertheless, a better understanding of trace fossils can be obtained if modern animals are studied in the context of their trace-making behaviors. Herein, we explore the more common traces observed in modern environments and associate those traces to groups of animals. This paper particularly focuses on the infaunal behavior of invertebrates in marginal-marine and marine settings. The main groups of animals considered herein are: vermiform nemerteans, polychaetes and hemichordates; a range of marine crustaceans; bivalves; motile echinoderms; and, to a lesser degree, sponges and sea anemones. These groups of animals were chosen on the basis of their abundance in marine environments, the common occurrence of ichnofossils similar to their traces, and the many studies of their trace-making behavior. Animals that bore into hard substrates are not reported, as such studies have been previously performed and are not discussed here (e.g. Kelly \& Bromley 1984, Bromley 1994). The aim of the present work is not to suggest limitations to the interpretations of trace fossils, but to increase the range of possible interpretations.

\section{MATERIALS AND METHODS}

Most data on modern traces are collected using 1 of 3 methods: (1) manual excavation of sediment in intertidal zones, with careful splitting of the sediment along and perpendicular to bedding planes; (2) resin or plaster casts of burrows, whereby a burrow is flooded with polyester, polyurethane resin, or plaster, and the cast is removed upon hardening of the substance (e.g. Bouma 1969); and (3) collection and slabbing of sediment boxcores followed by X-ray imaging (e.g. Gingras et al. 1999, 2001, Dashtgard \& Gingras 2005a). Manual excavation is used in intertidal zones, casting has been conducted in intertidal and shallow subtidal settings, and box-coring is used from intertidal to deep waters. Another means of determining trace morphology is to place burrowing animals in aquaria and study the resultant burrow morphologies (e.g. Dafoe et al. 2008). Aquaria have also been used in situ in sedimentary studies and removed after a time for laboratory analysis (Dashtgard \& Gingras 2005b).

\section{RESULTS}

\section{Vermiform nemerteans, polychaetes and hemichordates}

Worm-like animals represent a very important group of macroscopic bioturbators in marine settings. They are diverse and can be exceedingly abundant: $>10000$ species of marine polychaetes are known (Rouse \& Fauchald 1998). Within the Polychaeta, most reported (ichnological) observations are associated with members of the subclasses Palpata (Glyceridae, Nephtyidae, Nereididae, Serpulidae, Sabellidae, Spionidae, Pectinariidae and Terebellidae) and Scolecida (Arenicolidae, Capitellidae, Maldanidae, Opheliidae and Paraonidae).

Nemerteans are often free swimming, but some are common burrowers (e.g. Cerebratulus of the family Lineidae), living infaunally in marginal-marine settings. Although less common, the burrows of vermiform hemichordates (class Enteropneusta or 'acorn worms') are well studied because hemichordates represent the 'evolutionary link' between invertebrates and vertebrates. Two important genera of enteropneusts are Saccoglossus and Balanoglossus. Saccoglossus favors shallow marine waters and Balanoglossus appears to be more abundant in deeper waters (Chris Cameron pers. comm.).

The commonest morphology of worm burrows is a simple vertical tube or shaft (Figs. 1A \& 2A). From such tubes, worms filter feed in the water column (e.g. sabellariids), gather food from the sediment-water interface (e.g. terebellids, maldanids and glycerids), deposit feed (maldanids and capitellids), or engage in passive carnivory (e.g. Cerebratulus). More exotic uses of vertical tubes include gathering stock chemicals for chemobiosis (Romero-Wetzel 1987, Hertweck et al. 2005) or attracting vagile pore-living animals (Minter et al. 2007). The most common modification of the vertical shaft is transformation into a Y-form. This behavior is exemplified by nereid polychaetes, which are observed to extend their burrows laterally with serial Y-branches (Figs. 1C \& 2B,C). A second common modification is the establishment of a basal tunnel, which can run horizontally and may be connected to the sediment-water interface laterally (Fig. 1C). The basal tunnel may be observed to branch. Where preserved in the rock record, these structures will generally be assigned to the ichnotaxa Skolithos (vertical shaft), Polykladichnus (Y-shape), Planolites (actively filled, horizontal tube), or Palaeophycus (lined tube). To varying degrees, such traces are made by nereids, glycerids, nephtyids, nemerteans and the hemichordate Balanoglossus (Gingras et al. 1999, Hertweck et al. 2005, 2007). Burrows that branch basally and possess a single vertical connection to the sediment-water interface, such as those commonly made by nereid and capitellid polychaetes, may produce traces similar to Chondrites (Hertweck et al. 2007).

Another common feature of worm-generated tubes is the addition of a lining. Lined vertical burrows are typically unbranched. Linings can be thin and litho- 


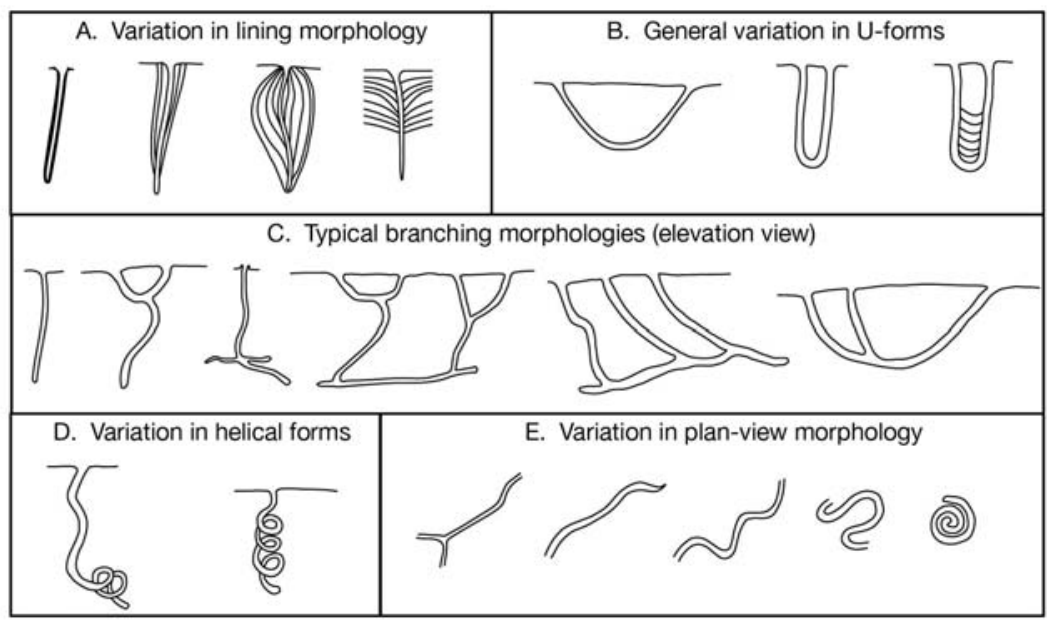

Fig. 1. Variations in worm burrows. (A) Burrow lining types: concentric and thin, through tapered or spindle-shaped. Also, Tasselia-like lining is shown on right. (B) Broad, narrow, and Diplocraterion-like U-shaped burrows. (C) Morphological variation in Y-shaped burrows. (D) Helicolithus- and Gyrolithes-type helical burrows. (E) Branching, sinuous, meandering, and coiled forms of intrastratal horizontal burrows

logically distinct, such as the brick-layer style sand tubes of pectinariids, or may comprise mucus-bound sediments, such as those installed by maldanid worms (Fig. 1; Bromley 1996). Although visibly discernible from their unlined counterparts, lined shafts are still assigned to Skolithos in the sedimentary record. Tubes with armored linings (i.e. lined with mucus and other material, such as sediment or shell fragments) may be ascribed to Schaubcylindrichnus. In some burrows, the lining is observed to be extravagantly over-thickened, typically with fine-grained clastics. This is commonly accompanied by a flaring of the lining, producing the spindle-shaped lining commonly observed in terebellid polychaete burrows (Aller \& Yingst 1978, Nara 1995, Gingras et al. 1999), or a drum-shaped morphology (Wetzel \& Bromley 1996). Flared or tapered structures in the rock record would be described as Cylindrichnus or Rosselia (Figs. 1A \& 2H). In graveldominated sediments, terebellid polychaetes commonly deposit feed within the sediment and do not require a tube opening at the sediment-water interface. In these cases, the resultant burrow is similar in form to Asterosoma (Dashtgard et al. 2008).

A morphological advancement of the simple shaft is the U-shaped burrow, resulting in an Arenicolites-like trace (left and middle traces, Fig. 1B). Although similar in form to Y-shaped burrows (Fig. 1C), U-shaped burrows serve a fundamentally different feeding strategy. Nereid worms seem to generally employ a Y-morphology and are seldom observed in simple U-burrows, whereas animals that commonly use U-shaped burrows (such as arenicolids) show no predisposition to add a descending Y-branch. This seems to reflect basic functionality: Y-burrows are more commonly used for interface feeding and protection, where access to the detritusladen surface is enhanced by an extra opening, and extra openings reduce the risk of predation. U-burrows are more commonly dedicated to conveyer-belt feeding strategies (i.e. arenicolids; Swinbanks 1981) or filter feeding (spionids; Gingras et al. 1999). Basic U-form burrows can be modified by extending or shifting the U-structure and, thereby, generating a spreite. U-burrows with spreiten are assigned to the ichnogenus Diplocraterion, diminutive examples of which have been observed to be made by spionid polychaetes (Schäfer 1972, Pemberton \& Frey 1985, Gingras et al. 2001) and arthropods (Richter 1926, Seilacher 1964, Schäfer 1972). Larger rock-record examples (such as Diplocraterion habichi) may well have been produced by nemerteans or nereid polychaetes, but modern examples of large Diplocraterion have not been reported.

An important twist on vertical shaft architectures is the imposition of a corkscrew morphology, resulting in the trace fossils Helicolithus and Gyrolithes (Figs. 1D \& $2 \mathrm{~F}, \mathrm{G})$. Such traces have only been observed in modern settings in association with capitellid polychaetes (Howard \& Frey 1975) and decapod shrimp (Dworschak \& Rodrigues 1997; discussed in 'Materials and methods-Marine crustaceans'). The morphology is also observed as a component of some enteropneust burrows (Saccoglossus; Gingras et al. 1999), but, in those cases, the corkscrew generally resides at the terminal end of the lower burrow (Fig. 2F,G). Although the trace fossil Gyrolithes has been linked to salinityinduced stresses in the rock record (MacEachern et al. 1999), modern occurrences seem to be more strongly associated with either anchoring of the worm (e.g. Saccoglossus), a response to high-density colonization (e.g. capitellids; M. K. Gingras pers. obs.), or may represent a focused, 3D deposit-feeding structure (M. K. Gingras pers. obs.)

The range of morphologies on the horizontal components of worm burrows are expressed in their planiform configuration. As suggested above, worm burrows may branch near the surface. Such structures facilitate interface feeding, reduce the risk of predation, and possibly allow passive carnivory (all of these general behaviors are discussed in Seilacher 1964). Tubes or burrows may also be sinuous to meandering horizontal tunnels, with or without branches. Nereid polychaetes commonly construct 3D horizontal networks (Fig. 1E), from which branches extend to the 

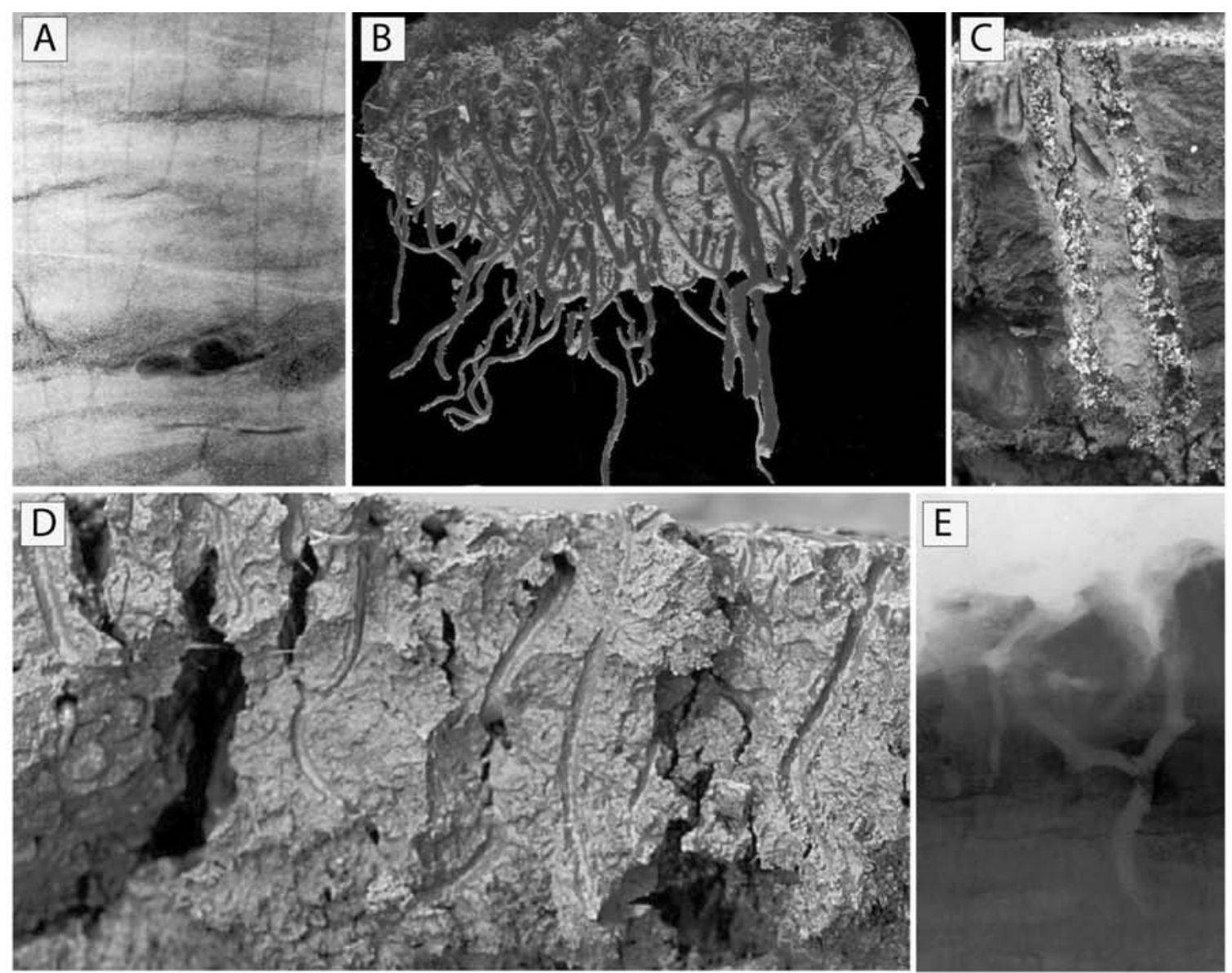

E

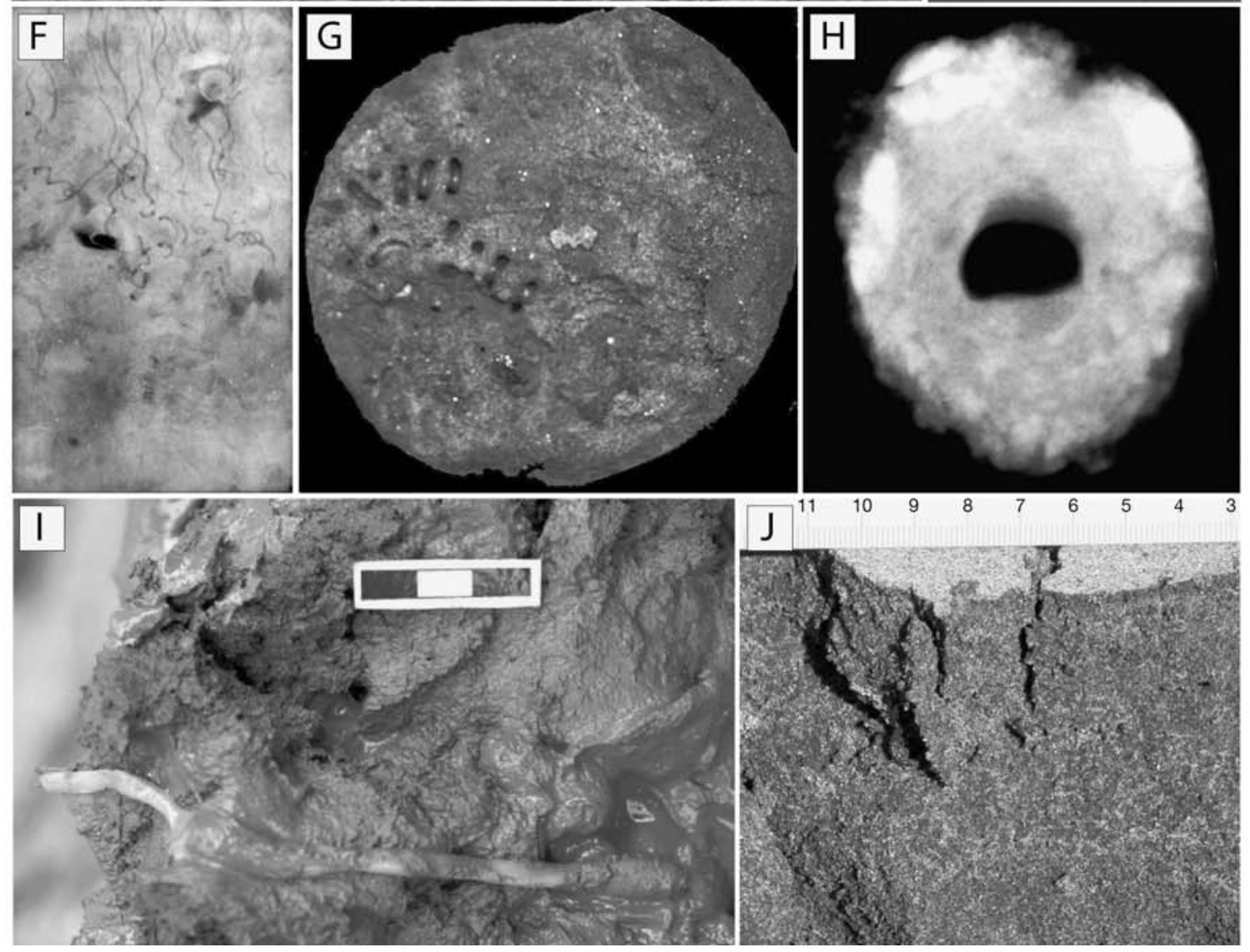


Fig. 2. Worm burrows. (A) Incipient Skolithos from tidal sands, Ogeechee Estuary (X-ray image); tracemaker not ascertained. Field of view: $12 \mathrm{~cm}$. (B) Resin cast of Y-shaped burrows of Nereis from Kouchibouguac Estuary, Canada. Field of view: $34 \mathrm{~cm}$. (C) Reamed vertical tube with concentric lining from Bay of Fundy, Canada. Field of view: $2.5 \mathrm{~cm}$. (D) Nereid polychaetes and incipient Polykladichnus from muddy sediments of Shepody Estuary, Canada. Field of view: $15 \mathrm{~cm}$. (E) X-ray image Polykladichnus, Bay of Fundy, Canada. Field of view: $14 \mathrm{~cm}$. (F) Saccoglossus (enteropneust) burrows, X-ray image from Bay of Fundy, Canada. (G) Exposed parts of Saccoglossus burrows from shallow core (Willapa Bay, USA). Field of view: $10.5 \mathrm{~cm}$. (H) Cross section of thickened burrow wall (Rosselia) from modern terebellid polychaete (Bay of Fundy, Canada). Field of view: $4 \mathrm{~cm}$. (I) Palaeophycus-dwelling nemertean, Cerebratulus, Shepody estuary, Canada. Scale bar: $3 \mathrm{~cm}$. (J) Macaronichnus made by opheliid polychaete, Euzonus. Pachena Beach, Vancouver Island

sediment-water interface. These burrow networks are semi-permanent structures that allow the worm to move quickly through the sediment and deposit feed over a larger area (Hertweck et al. 2007, Gingras et al. 1999, Dashtgard \& Gingras 2005a). Opheliid polychaetes also move horizontally though the sediment and backfill their burrows as they relocate. Opheliids are, in part, deposit feeders that are constantly shifting in search of food (Clifton \& Thompson 1978, Saunders \& Pemberton 1990). As such, a permanent burrow structure would be impractical. Permanent horizontal burrow networks are similar to the trace fossil Palaeophycus, whereas temporary burrows of mobile feeders are similar to Planolites. Opheliids are also known tracemakers of Macaronichnus (Fig. 2G). Unbranched horizontal burrows are difficult to observe in modern settings, but have been inferred from X-rays of boxcores collected from deeper-water deposits (Wetzel 1991, 2002). Such burrow forms probably record deposit-feeding behaviors - such as that interpreted for the trace fossil Chondrites - and may be produced by polychaetes (Hertweck et al. 2005). Non-branched horizontal burrows are similar in morphology to the trace fossils Planolites, Helminthopsis, Phycosiphon, and Cochlichnus.

In summary, worm burrows from modern settings show a wide range of burrow morphologies that can be directly applied to the rock record. Some of the burrow forms, such as vertical shafts and branched horizontal burrow networks have a wide range of ethological uses. Other forms, such as Y- and U-shaped burrows, and corkscrew-shaped burrows seem to indicate more localized niches. Modifications on planiform morphology are dominantly dedicated to deposit-feeding initiatives.

\section{Marine crustaceans}

The range of burrowing marine arthropods is broad. Dominant in this group are isopods, amphipods and decapods, to which we restrict the discussion below. Isopods are a diverse order of crustaceans common to shallow marine waters. Amphipods include >7000 species of small, shrimp-like crustaceans, most of which occupy marine settings. The order Decapoda includes crayfish, crabs, lobsters, prawns, and shrimp. In marine settings, the trace-fossil record is dominated by thalassinid shrimp and amphipods and, to a far lesser degree, the burrows of crabs, stomatopods, and lobsters (Fig. 3).

Isopods are relatively flat, robust animals that scavenge and deposit feed within the intertidal zones of modern sand-dominated shorelines. They excavate shallow burrows in the sediment during high tide, in order to avoid being eaten. As the falling tide exposes the sediment, the isopods move rapidly through watersaturated sediment, processing and extracting organic matter (Griffith \& Telford 1985, Hauck et al. 2008). In some cases, the pathways of these small crustaceans are preserved as displaced sedimentary laminae produced by their infaunal, 'sediment-swimming' movement: these traces have no clear taxonomic affinity. The surface trackways constructed by isopodsstraight to meandering to chaotically spiraling bedding-plane traces - can be ascribed to Gordia. Alternatively, where preservation is exceptional, a bilobate furrow may be evident, and the resulting trace can be classified as Isopodichnus.

Amphipods are another major group of burrowing organisms in marginal-marine settings. In sandy backshore settings, talitrid amphipods construct vertical, unlined burrows similar in form to Skolithos (Dashtgard \& Gingras 2005b). Within the intertidal zone, 2 main burrowing amphipods are commonly found, Corophium sp. and Haustorius sp. Corophium volutator is a mud-loving shrimp, which occurs in population densities up to $63000 \mathrm{~m}^{-2}$ in semi-firm mud substrates (Thurston 1990, Pearson \& Gingras 2006). It constructs a U-shaped tube that, during high tide, allows the amphipod to breathe, feed, and evacuate waste material from the safety of its burrow. C. volutator burrows are similar to Arenicolites. With time, this tube is deepened resulting in the development of Diplocraterion (Fig. 4G) (Richter 1926, Seilacher 1964, Schäfer 1972). A second Corophium species, C. arenarium, is common in sandy substrates within the intertidal zone. $C$. arenarium constructs a single vertical shaft in sand as water flows freely through the burrow walls and does not require an exit shaft. These burrows are similar in 

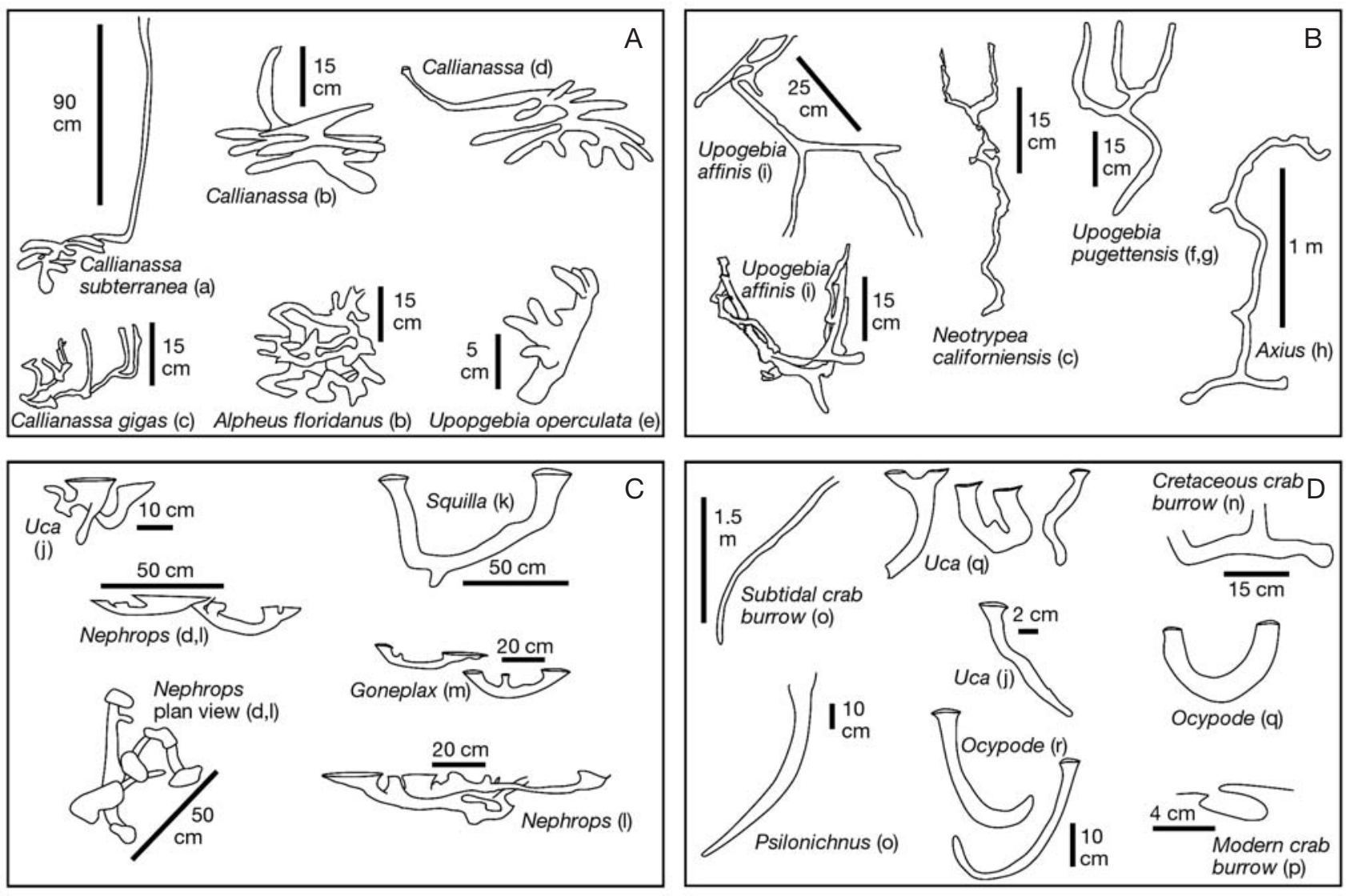

Fig. 3. Variations in crustacean burrows represented by schematic diagrams of resin casts and trace fossils. Thalassinid burrows with (A) a simple subapertural shaft and a complex deposit feeding architecture and (B) with modified U-shaped subaperture and simple or absent basal architectre. (C) Crab, lobster and mantis burrows with complex subaperture and no basal architecture; (D) Crab burrows with a simple J-, U-, or Y-shaped subaperture and no basal architecture. For (A,B) shafts and tubes have a circular cross-section and burrows are (A) commonly lined, or (B) rarely lined. For (C,D) irregular or ovate cross-sections are common and burrows are generally unlined. Note overall higher complexity of basal portion of thalassinid burrows compared to lobster and crab burrows. Lobster burrows demonstrate more complex branching in sub-aperture portion of burrow; crab burrows commonly display simplest architectures. Sources indicated by letters beside burrow schematics are as follows: (a) Atkinson \& Nash (1990), (b) Shinn (1968), (c) Griffis \& Chavez (1988), (d) Rice \& Chapman (1971), (e) Kleeman (1984), (f) Dworschak (1982), (g) Stevens (1929), (h) Pemberton et al. (1976), (i) Frey \& Howard (1975), (j) Basan \& Frey (1977), (k) Myers (1979), (l) Farmer (1974), (m) Atkinson (1974), (n) Richards (1975), (o) Humphreys \& Balson (1988), (p) Savazzi (1982), (q) Farrow (1971), (r) Frey et al. (1984), (s) Fürsich (1981)

form to Skolithos. The surface locomotion trackways of Corophium and of free-swimming marine amphipods have not been classified.

Haustoriid amphipods - a group of burrowing amphipods - also occur in intertidal settings. Haustoriids are commonly referred to as digger amphipods, as they move through the sediment by excavating and backfilling their burrow as they move. The smaller species of this group of amphipods are only a few millimeters long and tend to contribute to the formation of cryptobioturbation (see 'Biodeformational structures' below). Large specimens, however, disrupt the sediment (Fig. 4F) (Howard \& Elders 1970).

Thalassinid shrimp are the best known of crustacean burrowers, producing traces conspicuous in their size and geometry. The basic form of most thalassinid shrimp burrows is a vertical shaft connected to the sediment-water interface, which branches at depth (Shinn 1968, Griffis \& Chavez 1988, James et al. 1990). The range of thalassinid traces is summarized in Fig. 3A and Fig. 4A,B. Fossilized, these traces are known collectively as Thalassinoides. The upper part of the burrow, referred to as the aperture, may split and narrow, forming a small Y-shape. This is rarely preserved in the rock record. Thalassinid shrimp burrows may display complex basal structures (Fig. 3A) including tiered and box-worked networks (Shinn 1968, Griffis \& Chavez 1988, James et al. 1990). In general, thalassinid shrimp use the vertical shaft to maintain a connection to the sediment-water interface, and the basal network for deposit feeding. The large volume of thalassinid burrows also permits shrimp to moderate the burrow 

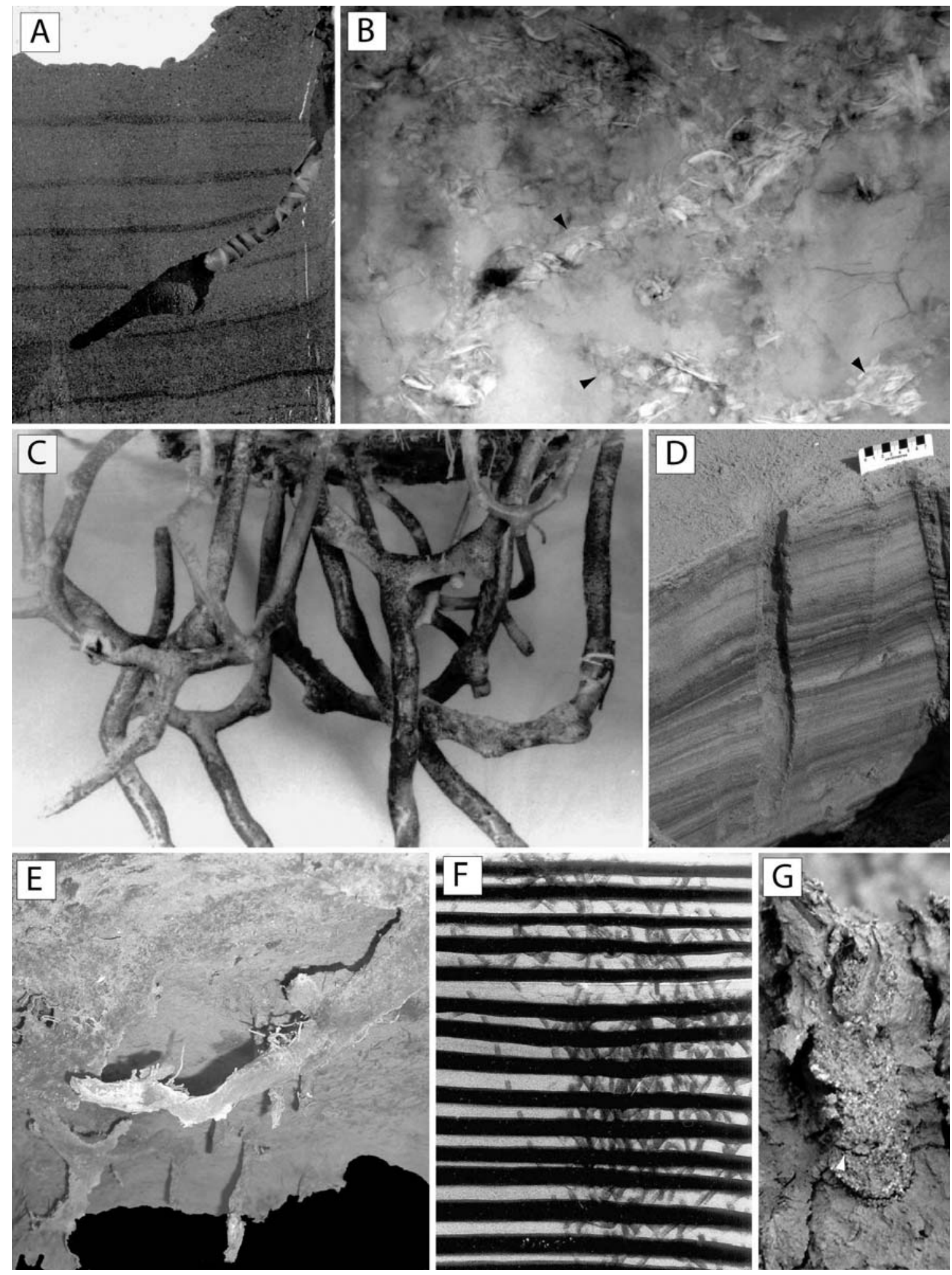

Fig. 4. Crustacean burrows. (A) Neotrypaea californiensis (thalassinid) in a laminated aquarium. Image shows swollen turning chamber and typical Thalassinoides morphology. Field of view: $14 \mathrm{~cm}$. (B) X-ray of thalassinid burrows filled with shell material (black arrowheads), Ogeechee Estuary, USA. Field of view: $25 \mathrm{~cm}$. (C) Resin cast of burrows of Upogebia pugettensis from Willapa Bay, USA. (D) Vertical part of incipient Psilonichnus made by crabs, Ogeechee Estuary, USA. (E) Resin cast of Hemigrapsus oregonensis from Willapa Bay, USA. Field of view $\sim 20 \mathrm{~cm}$. (F) Sediment mixing by haustoriid amphipods in thin-walled aquarium. (G) Incipient Diplocraterion made by amphipod Corophium volutator. Field of view: $2 \mathrm{~cm}$ 
chemistry in intertidal settings and in locales characterized by salinity fluctuation (Thompson \& Pritchard 1969). The genus Upogebia tends to maintain a Yshaped burrow (Fig. 4C) (cf. Polykladichnus) that the animal employs for filter feeding, using the descending branch as a protective domicile (Stevens 1929, Dworschak 1982). This is a different use of the Y-structures constructed by worms, in that polychaetes activate this strategy for focused interface-feeding activities. Thalassinid shrimp are also known to make large, Gyrolithes-style helical burrows (Dworschak \& Rodrigues 1997). These burrows are identical to those produced by vermiform animals, except that the trace is much larger and bioglyphs may be imprinted on the burrow wall (Wetzel 2007). It is more likely that the shrimp use such architectures to produce a spiral ramp for the easy maintenance of their domiciles, or that this is a response to high population densities within shrimp species otherwise not known for gregarious behavior.

Shrimp burrows may be pellet-, mud-, and mucuslined (Pemberton et al. 1976, Frey et al. 1978) but can vary appreciably. These are normally used in shifting substrates and, in the rock record, would be considered stabilized variants of the trace fossil Thalassinoides. In general, pellet-walled shrimp burrows would be ascribed to the ichnogenus Ophiomorpha.

Modern crab burrows have many characteristics that are not generally seen in burrows made by other crustaceans (Figs. 3C,D \& 4D,E). These include comparatively simple architectures (U-, Y-, and J-shaped), open apertures and irregular ovoid cross sections (Fig. 3C,D). Crab burrows are normally unlined (Atkinson 1974, Curran \& White 1991, Gringras \& Pickerill 2002) and can be interpreted as Psilonichnus (Frey \& Pemberton 1987, Pemberton et al. 2001). Because crab burrows represent domiciles as opposed to combined feeding structures, complex basal geometries are absent. The architectures of crab and lobster traces are similar, although lobster burrows normally display shallower, sub-apertural branching (Rice \& Chapman 1971, Farmer 1974) and possess more irregular burrow diameters (Fig. 3C,D). No widely used ichnogenus resembles the irregular burrows constructed by lobsters; although the term Decapodichnus is informally ascribed (Pemberton et al. 1984).

\section{Marine bivalves}

There are 3 main types of bivalve traces (Fig. 5): (1) vertically oriented filter- or surface-deposit-feeding from a stationary location, (2) horizontal motility reflecting grazing near the sediment-water interface, and (3) rapid vertical movement through the sediment as an escape mechanism. Additionally, bivalves pro- cess reduced sediment-porewater compounds within their burrows.

Stationary, filter- and surface-deposit-feeding bivalves have been observed to produce columnar traces composed of 3 parts: (1) an ovate cavity situated around the bivalve; (2) possible equilibrichnial structures directly below or above the cavity, recording slight upward and downward movement; and (3) a vertical chimney or chimneys demarcating the location of the bivalve's extended siphon or siphons (Figs. 5 \& 6A-C) (Gingras et al. 2007). Similar structures in the rock record include Siphonichnus (Stanistreet et al. 1980), Scalichnus - an equilibrium trace fossil produced by Panopea (see Hanken et al. 2001) - and, to a lesser degree, Conichnus which normally only possesses Features 1 and 2 of the 3 main bivalve traces above (e.g. Savrda \& Uddin 2003). Conichnus represents the efforts of the animal to maintain a connection to the sedimentwater interface (Fig. 5). In the case of Siphonichnustype traces, the connection is maintained using a prehensile siphon. Notably, many bivalves also have a 'foot' that is capable of moving the organism up and down in the sediment, and producing equilibrichnia (menisci). Together, the siphon and the foot represent the primary means of sediment reworking.

A very common ichnofossil ascribed to bivalves is Lockeia. This is a small, almond-shaped depression indented by the foot of the bivalve during resting.
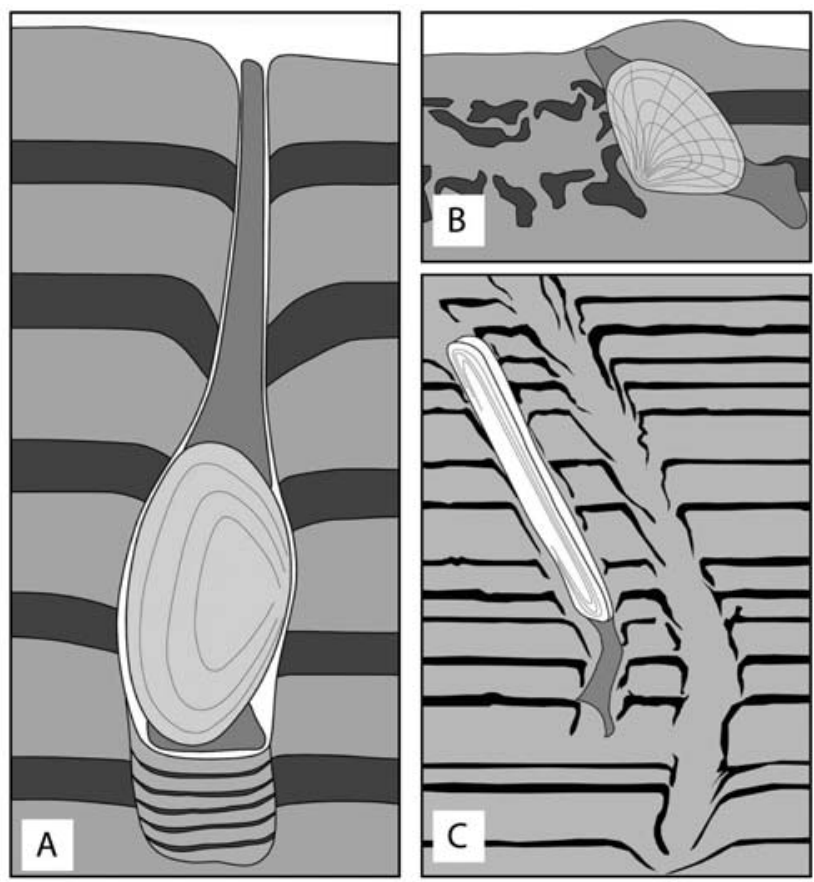

Fig. 5. Bivalve traces. (A) Vertically oriented bivalve produces Siphonichnus-type trace. (B) Disruption of sediment produced by horizontal movement of bivalve. (C) Escape structures (fugichnia) produced by upward escape behavior of mobile bivalves 

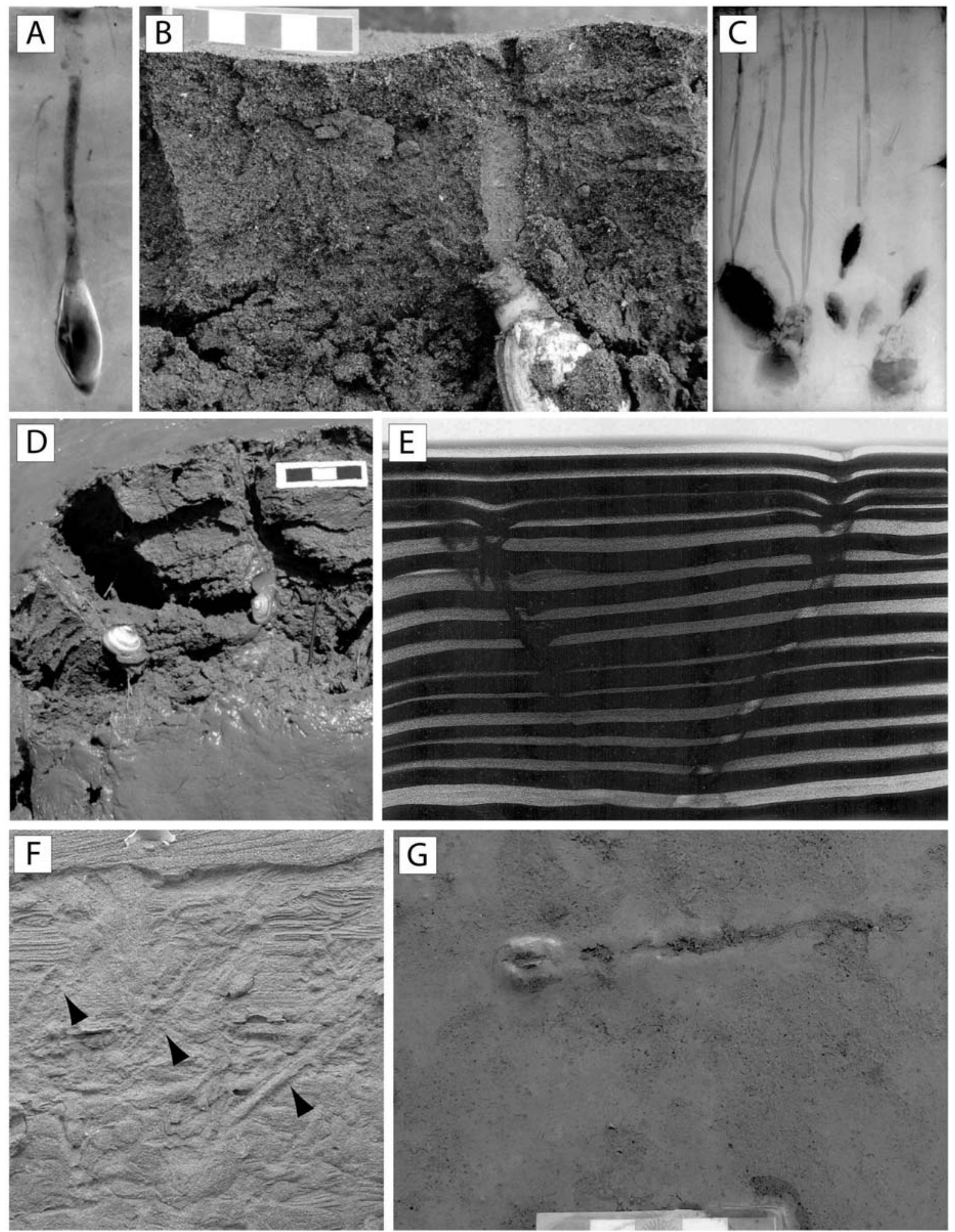

Fig. 6. Bivalve burrows. (A) Mya arenaria in situ; X-ray of shallow sediment core from Bay of Fundy, Canada. Field of view: $3.5 \mathrm{~cm}$. (B) M. arenaria in sandy sediment, Bay of Fundy, Canada. Scale bar: $5 \mathrm{~cm}$. (C) Split siphon of Macoma balthica results in paired connection to sediment-water interface. X-ray image from Kouchibouguac, Canada. Field of view: $14 \mathrm{~cm}$. (D) $M$. balthica in situ, Shepody estuary, Canada. Scale bar: $3 \mathrm{~cm}$ (E) Razor clam adjustment structures in thin-walled aquaria. Field of view: $25 \mathrm{~cm}$. (F) Resin peel of shallow box-core showing escape structure (black arrowheads point to escape traces) of modern razor clams. Field of view: $15 \mathrm{~cm}$. Courtesy of B. C. Yang. (G) Horizontal trail of M. balthica 
These structures are difficult to see in modern deposits, because they are preserved only at interstratal boundaries. They are best seen in bedding-plane views. Inferable structures have been identified in Xray images, and very well-developed examples (found with preserved in situ shells of Mya arenaria) have been reported from Recent sediments in the Bay of Fundy (Dashtgard \& Gingras 2005b).

Rapid vertical movements by bivalves are preserved almost solely as fugichnia (i.e. upwards-escape tracks). In modern deposits, this is caused by an abrupt sedimentation event and is observed as a wispy, downward deflection of sedimentary laminae. This behavior has been induced in aquaria, and captured in box-core peels (Figs. $5 \& 6 \mathrm{E}, \mathrm{F}$ ), but in the rock record it is exceedingly difficult to distinguish such structures from those produced by the escape response of other animals.

Horizontal movements of bivalves leave furrows and produce lateral deformations ascribed to the pushing of the foot (Figs. $5 \& 6 \mathrm{G}$ ). This has been likened to the production of Protovirgularia in the rock record (Seilacher \& Seilacher 1994). Much more complex (lateral) bivalve movements have been suggested in the case of Hillichnus loboensis, which was compared to the traces of modern tellinacean bivalves (Bromley et al. 2003), and in some complex bivalve motility tracks (Werner 2002).

\section{Motile echinoderms}

Motile echinoderms are represented by Eleutherozoa, which include the Asteroidea (starfish), Ophiuroidea (brittle stars), Echinoidea (sea urchins and sand dollars), and Holothuroidea (sea cucumbers). All of these animals leave distinctive traces in modern sediments.

Asteroids most commonly leave star-shaped resting traces preserved as the trace fossil Asteriacites (Gaillard 1991). It is also recognized that asteroids create motility traces that record their movement across the seafloor. Less well known are the predation traces produced by asteroids digging into shallow sediment to feed on bivalves.

Ophiuroids may move along the seafloor in a manner similar to asteroids, and can leave similar resting traces. Unlike starfish, however, the brittle stars have been observed buried in sediment with their arms stretched above the sediment-water interface (Howard \& Frey 1975). This filter-feeding behavior has been reported from various shallow marine settings. The resulting trace is a conical to chevron-shaped disruption of the sediment that has not been reported from the rock record (Fig. 7C), but which could be confused with Lingulichnus or Cylindrichnus in poorly displayed cross-sections.

Echinoids - such as heart urchins (spatangoids) can be extremely mobile, especially in sandy substrates. These animals move through the shallow sediment by passing sediment grains under their bodies using their tube feet. The resulting trace, shown from $\mathrm{X}$-ray images of laboratory aquaria and sediment boxcores, can be a very finely and regularly backfilled passage (Fig. 7D,E) (Bromley \& Asgaard 1975, Wetzel 1981, Fu \& Werner 2000). Not all spatangoids produce a finely back-filled trace, however, with such traces ranging from laminated to crudely backfilled (Bromley \& Asgaard 1975, Kanazawa 1995). The backfilled burrows produced by sand dollars (very thin and very shallow: M. K. Gingras pers. obs., Parksville, British Columbia, 2006), sea biscuits, and heart urchins are similar. However, identification of the resultant trace is dependent upon the size and shape of the tracemaker. Backfilled structures constructed by heart urchins are the most conspicuous of these trace fossils, due to their larger cross-sectional width. The very flattened form of sand dollar traces would likely inhibit their identification as trace fossils. Backfilled echinoid tunnels can be broadly classified as Scolicia or Bichordites, although true Scolicia and Bichordites should show evidence of a preserved axial canal or canals near the center of the trace fossil. Such details are hard to identify in modern sediments and are, in part, dependant on the grainsize of the sediment (Wetzel 1981). Sand dollars are known to orient themselves vertically within the sediment in a manner similar to brittle stars, such that part of their body is buried and part extends above the sediment-water interface (O'Neill 1978). This behavior is likely to produce small chevron-shaped disruptions virtually identical to the aforementioned brittle star's traces.

Sea cucumbers are probably responsible for a broader range of trace fossils than have been ascribed to them in the ichnological literature. They make crude, sinuous trails at the sediment-water interface and large, also crude, bow-shaped Arenicolites-type burrows in intertidal settings (Fig. 7A,B) (Howard 1968). Their ability to burrow infaunally suggests that at least some irregular disruptions of sediment in the rock record could be attributed to the burrowing activity of sea cucumbers.

\section{Sponges and sea anemones}

Although sponge traces are widely recognized as borings (e.g. Kelly \& Bromley 1984, Bromley 1994, 1996), their traces in soft sediment are limited to cupshaped resting marks. These traces range in size from 

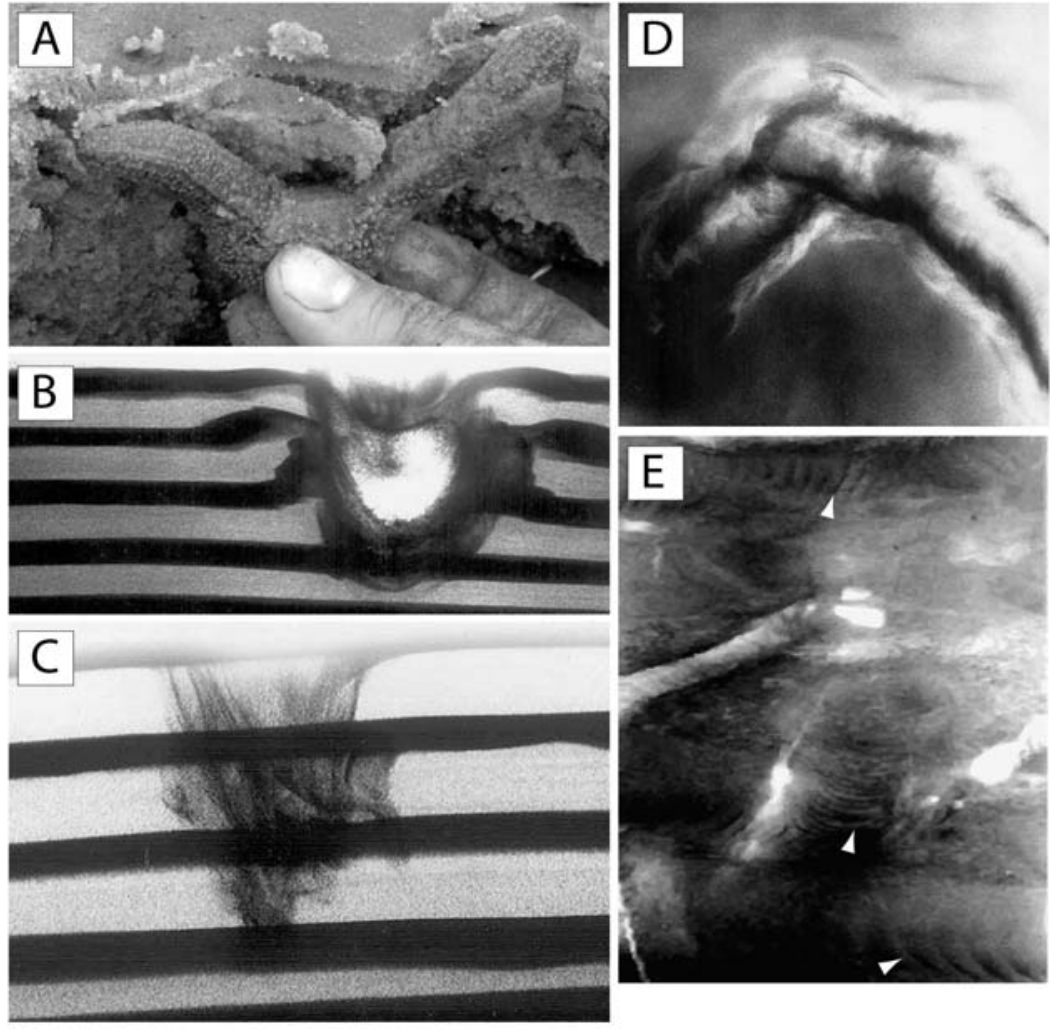

Fig. 7. Echinoderm burrows. (A) Sea cucumber, Thyone, living in Arenicoliteslike burrow, Ogeechee Estuary, USA. (B) X-ray image of Thyone in thin-walled aquarium. Field of view: $\sim 20 \mathrm{~cm}$. (C) Typical intrusive structure produced by brittle star. Field of view: $13 \mathrm{~cm}$. (D) X-ray image of sea urchin, Moira, from aquarium study. Field of view: $25 \mathrm{~cm}$. (E) Digitized tracing of X-ray image of shallow sediment core bioturbated by heart urchins. Field of view: $14 \mathrm{~cm}$. Arrowheads: mensicate backfill of echinoid passage

centimeter-scale to decimeter-scale, and they generally do not exceed a few centimeters in depth. Sea anemones, in contrast, can produce large, penetrative biogenic structures. The burrowing anemone, Cerianthus, for example, may reach $70 \mathrm{~cm}$ in length, and can burrow to almost that depth within the sediment (Hargitt 1907). The animal protrudes out of its burrow to hunt, and retracts to nearly full depth to take shelter. Its iterative probing up through the sediment produces a collapsed, chevron-shaped trace fossil that is conical in cross-section (Fig. 8). Cerianthus is also very capable of re-establishing its position with respect to the sediment-water interface, such that its dwelling trace can show notable aggradation in response to sedimentation events. Only small anemones have been imaged from X-rays of box-cores, but their traces are nearly identical to the trace fossil Conichnus. Buck \& Goldring (2003) noted the similarity of conical structures attributed to anemones and various structures produced by dewatering or degassing. This suggests caution should be used when interpreting potential anemone-made structures in the rock record.

\section{Biodeformational structures}

Biodeformation structures (sensu Schäfer 1956) include macro-scale deformation, and cryptobioturbation or cryptic bioturbation. Cryptic bioturbation is a common texture in marginal-marine depositional environments. The activities of meiofauna (animals between 0.1 and $1 \mathrm{~mm}$ ) and very small macrofauna blur or mottle the original sedimentary fabric, resulting in the development of a cryptobioturbate texture (Howard \& Frey 1975, Bromley 1996). Whereas the macrofauna discussed above either excavate a penetrative burrow or disrupt the sediment to the point that primary sedimentary structures are destroyed, meiofauna shift grains only slightly as they move and feed between them. In sandy substrates, the mass of meiofauna occupying the sediment may far exceed the macrofaunal population mass. Despite this, meiofaunal disruption of the sediment is commonly ignored, because some primary sedimentary fabrics are still visible even in $100 \%$ cryptobioturbated substrates. In tropical environments, complete homogenization of sediments by meiofauna has been reported to occur in as little as a few days (Thayer 1983, Bromley 1996).

Biodeformational structures are features such as 'mantle and swirl' (Schäfer 1956, Lobza \& Schieber 1999, Schieber 2003) and sediment-swimming structures. Mantle and swirl structures occur where burrows cross sedimentary layers and obscure the bedding contacts, with the burrow infills displaying an array of complex, convoluted features due to mixing of soupy sediment. Sediment-swimming structures result from an animal passing through fluid-rich substrate. Such structures blur sedimentary laminae, but do not produce a distinct burrow, and develop mainly through the burrowing activity of macrofauna, such as nephtyid polychaetes and isopods. The biosedimentary textures generated are similar to cryptobioturbation.

\section{DISCUSSION}

The majority of marine trace fossils can be attributed to invertebrates. Studies from modern settings have revealed tracks and burrows analogous to many trace fossils, including Arenicolites, Asterosoma, Cochlichnus, Conichnus, Cylindrichnus, Diplocraterion, Gordia, Gyrolithes, Helminthopsis, Isopodichnus, Ophiomorpha, Lockeia, Palaeophycus, Planolites, Polykladich- 


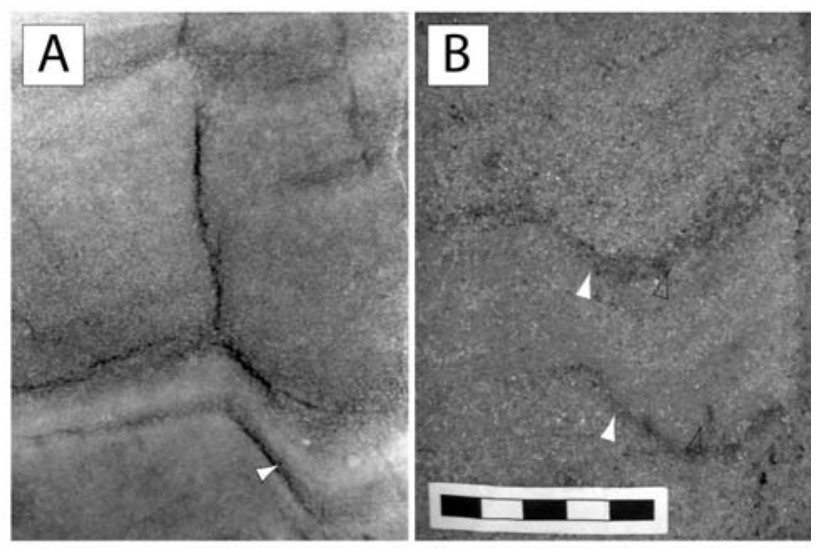

Fig. 8. Anemone burrows. (A) Conichnus-like structure from X-ray image, Ogeechee Estuary, USA. Field of view: $10 \mathrm{~cm}$. (B) Slabbed box-core showing sediment disruption around anemone, Ogeechee Estuary, USA. Arrowheads: anemone trace. Scale bar: $5 \mathrm{~cm}$

nus, Protovirgularia, Psilonichnus, Rosselia, Scolicia, Siphonichnus, Skolithos, Taenidium, and Thalassinoides, as well as biodeformational textures. This is a conservative list. More complex ichnofossils have been interpreted in the context of neoichnological data (e.g. Neonereites [Martin \& Rindsburgh 2007] and Hillichnus). Some traces have been identified (in modern sediments) from deep-water studies, but the tracemakers are not known: Zoophycos, Phycosiphon, and Chondrites are commonly reported from sedimentary core, but without the tracemaker retained (Wetzel 1991). Other deep-water trace fossils (e.g. graphoglyptids or patterned trace fossils) are unknown from modern deposits or are only rarely reported. Spirorhaphe, Cosmorhaphe, and Paleodictyon have been observed as grooves in the tops of washed cores (without their tracemakers; Ekdale 1980), whilst Paleodictyon has been reported once from submarine surveys (Rona et al. 2003). Most trace fossils can be associated with a tracemaker only by inference. Analogues of other trace fossils probably will be discovered as studies of deepmarine settings increase.

A fundamental tenet of ichnology is that trace fossils should not be identified or characterized with respect to the inferred tracemaker, because fossil behavior is evolutionarily convergent. In other words, the behavior of a shrimp making a Skolithos-type trace is thought to be the same as a worm constructing a similar trace. However, many morphologically similar traces are produced for different reasons by different groups of animals. Large, open horizontal networks serve as domiciles and deposit-feeding structures for crustaceans, but are built by worms mainly for passive carnivory or for expanding an interface-feeding network. The trace fossil Gyrolithes potentially represents a mechanical ramp made by a shrimp or a holdfast produced by worms. Similarly,
Y-shaped burrows are used for filter feeding by shrimp, and interface deposit feeding by worms. These examples emphasize that inferences of behavior in the rock record are interpretive. Moreover, recurring associations of trace fossils (i.e. ichnofacies) are based upon the most likely (interpreted) behavior linked to a trace fossil. This does not reduce the utility of ichnofacies, but it does suggest that in settings characterized by lower diversities of trace fossils (e.g. brackish-water settings), the application of accepted ichnofacies can be extremely misleading.

Although linking a trace fossil to a tracemaker is not necessarily critical to an ichnological study, we contend that ichnological research can clearly benefit from such efforts. By understanding the life strategies employed by infauna in modern environments and how the traces they produce aid in survival, we can better assess the likely habits represented by individual and groups of trace fossils preserved in the rock record. Infaunal organisms respond to environmental stresses; by assessing organism and community response to various environmental stresses, it is possible to establish relations between ichnofossils, ichnological communities, and sedimentary processes. These links can be used to refine paleoenvironmental interpretations of the rock record and identify or predict spatial changes in the sedimentary environment.

Acknowledgements. Thanks to Dr. Kerrie Bann and Tom Saunders for continued insights into burrowing animals; also to Tyler Hauck and Lynn Dafoe for new insights regarding the distribution and behaviors of marginal-marine bioturbators. This manuscript was substantively improved by the reviews and input provided by Andreas Wetzel and 2 anonymous reviewers. Funding for research in neoichnology was generously provided by a Natural Science and Engineering Research of Canada (NSERC) Discovery Grant to M.K.G.

\section{LITERATURE CITED}

Aller RC, Yingst JY (1978) Biogeochemistry of tubedwellings: a study of the sedentary polychaete Amphitrite ornata (Leidy). J Mar Res 36:201-254

Atkinson RJA (1974) Behavioural ecology of the mud-burrowing crab, Goneplax rhomboides. Mar Biol 25:239-252

Basan PB, Frey RW (1977) Actual-palaeontology and neoichnology of salt marshes near Sapelo Island, Georgia. In: Crimes TP, Harper JC (eds) Trace fossils. Geol J (Spec Issue 9) 2:41-70

Bertling M, Braddy SJ, Bromley RG, Demathieu GR and others (2006) Names for trace fossils: a uniform approach. Lethaia 39:265-286

Bouma AH (1969) Methods for the study of sedimentary structures. John Wiley \& Sons, New York

Bromley RG (1994) The palaeoecology of bioerosion. In: Donovan SK (ed) The palaeobiology of trace fossils. Johns Hopkins University Press, Baltimore, MD

Bromley RG (1996) Trace fossils: biology, taphonomy and applications. Chapman \& Hall, London

Bromley RG, Asgaard U (1975) Sediment structures produced 
by a spatangoid echinoid: a problem of preservation. Bull Geol Soc Den 24:261-281

Bromley RG, Uchman A, Gregory MR, Martin AJ (2003) Hillichnus lobosensis igen. et isp. nov., a complex trace fossil produced by tellinacean bivalves, Paleocene, Monterey, California, USA. Palaeogeogr Palaeoclimatol Palaeoecol 192:157-186

Buck SG, Goldring R (2003) Conical sedimentary structures. Trace fossils or not? Observations, experiments, and review. J Sediment Res 73:338-353

Clifton HE, Thompson JK (1978) Macaronichnus segregatis: a feeding structure of shallow marine polychaetes. J Sediment Petrol 48:1293-1302

Curran HA, White B (1991) Trace fossils of shallow subtidal to dunal ichnofacies in Bahamian Quaternary carbonates. Palaios 6:498-510

Dafoe LT, Gingras MK, Saunders TDA, Pemberton SG (2008) Determining Euzonus mucronata burrowing rates with application to ancient Macaronichnus segregatis tracemakers. Ichnos (in press)

Dashtgard SE, Gingras MK (2005a) Facies architecture and ichnology of recent salt-marsh deposits: Waterside Marsh, New Brunswick, Canada. J Sediment Res 75:596-607

> Dashtgard SE, Gingras MK (2005b) The temporal significance and distribution of bioturbation in coarse-grained upper foreshore and backshore deposits: Waterside Beach, New Brunswick, Canada. Palaios 20:589-595

Dashtgard SE, Gingras MK, Pemberton SG (2008) Grain-size controls on the occurrence of bioturbation. Palaeogeogr Palaeoclimatol Palaeoecol 257:224-243

Dworschak PC (1982) The biology of Upogebia pusilla (Petagna) (Decapoda, Thalassinidae). PSZN I: Mar Ecol 4: 19-43

Dworschak PC, Rodrigues SA (1997) A modern analogue for the trace fossil Gyrolithes: the burrows of Axianassa australis (Decapoda: Thalassinidea: Laomediidae). Lethaia 30:41-52

Ekdale AA (1980) Graphoglyptid burrows in modern deepsea sediment. Science 207:304-306

Ekdale AA, Bromley RG, Pemberton SG (1984) Ichnology; the use of trace fossils in sedimentology and stratigraphy. SEPM Short Course 15, Society of Economic Paleontologists and Mineralogists, Tulsa, OK

Farmer ASD (1974) Burrowing behavior of the Norway lobster, Nephrops norvegicus (L.) (Decapoda: Nephropidae). Estuar Coast Mar Sci 2:49-58

Farrow GE (1971) Back-reef and lagoonal environments of Aldabra Atoll distinguished by their crustacean burrows. Symp Zool Soc Lond 28:455-500

Frey RW, Howard JD (1975) Endobenthic adaptations of juvenile thalassinid shrimp. Bull Geol Soc Den 24:283-297

Frey RW, Pemberton SG (1987) The Psilonichnus ichnocoenose and its relationship to adjacent marine and nonmarine ichnocoenoses along the Georgia coast. Bull Can Petrol Geol 35:333-357

Frey RW, Curran HA, Pemberton SG (1984) Tracemaking activities of crabs and their environmental significance: the ichnogenus Psilonichnus. J Paleontol 58:333-350

Fu S, Werner F (2000) Distribution, ecology and taphonomy of the organism trace Scolicia, in northeast Atlantic deepsea sediments. Palaeogeogr Paleoclimatol Palaeoecol 156: 289-300

Fürsich FT (1981) Invertebrate trace fossils from the Upper Jurassic of Portugal. Comunicacoes Servicos Geologicos de Portugal 67:153-168

Gaillard C (1991) Recent organism traces and ichnofacies on the deep-sea floor off New Caledonia, southwestern Pacific. Palaios 6:302-315
Gingras MK, Pickerill R (2002) Resin cast of modern burrows provides analogs for composite trace fossils. Palaios 17: 206-211

Gingras MK, Pemberton SG, Saunders T, Clifton HE (1999) The ichnology of modern and Pleistocene brackish-water deposits at Willapa Bay, Washington: variability in estuarine settings. Palaios 14:352-374

Gingras MK, Pemberton SG, Saunders T (2001) Bathymetry, sediment texture, and substrate cohesiveness: their impact on modern Glossifungites trace assemblages at Willapa Bay, Washington. Palaeogeogr Palaeoclimatol Palaeoecol 169:1-21

Gingras MK, Armitage IA, Pemberton SG, Clifton HE (2007) Pleistocene walrus herds in the Olympic peninsula area: trace-fossil evidence of predation by hydraulic jetting. Palaios 22:539-545

Griffis RB, Chavez FL (1988) Effects of sediment type on burrows of Callianassa californiensis Dana and C. gigas Dana. J Exp Mar Biol Ecol 117:239-253

Griffith H, Telford M (1985) Morphological adaptations to burrowing in Chiridotea coeca (Crustacea, Isopoda). Biol Bull 168:296-311

Hanken N, Bromley RG, Thomsen E (2001) Trace fossils of the bivalve Panopea faujasi, Pliocene, Rhodes, Greece. Ichnos 8:117-130

- Hargitt W (1907) Notes on the behavior of sea-anemones. Biol Bull 12:274-284

Hauck TE, Dashtgard SE, Gingras MK (2008) Relationships between organic carbon and Fodichnia morphology. Palaios 23:336-343

Hertweck G, Wehrmann A, Leibezeit G, Steffens M (2005) Ichnofabric zonation in modern tidal flats: paleoenvironmental and paleotrophic implications. Senckenb Marit 35:189-201

> Hertweck G, Wehrman A, Liebezeit G (2007) Bioturbation structures of polychaetes in modern shallow marine environments and their analogues to Chondrites group traces. Palaeogeogr Palaeoclimatol Palaeoecol 245:382-389

> Howard JD (1968) X-ray radiography for examination of burrowing in sediments by marine invertebrate organisms. Sedimentology 11:249-258

Howard JD, Elders CA (1970) Burrowing patterns of haustoriid amphipods from Sapelo Island, Georgia. Geol J Spec Issues 3:243-262

Howard JD, Frey RW (1975) Regional animal-sediment characteristics of Georgia estuaries. Senckenb Marit 7:33-107

Humphreys B, Balson PS (1988) Psilonichnus (Fürsich) in Late Pliocene subtidal marine sands of eastern England. J Paleontol 62:168-17

James R, Atkinson RJA, Nash RDM (1990) Some preliminary observations on the burrows of Callianassa subterrana (Montagu) (Decapoda: Thalassinidea) from the west coast of Scotland. J Nat Hist 24:403-413

Kanazawa K (1995) How spatangoids produce their traces: relationship between burrowing mechanism and trace structure. Lethaia 28:211-219

Kelly RA, Bromley RG (1984) Ichnological nomenclature of clavate borings. Palaeontology 27:793-807

Kleeman K (1984) Lebensspuren von Upogebia operculata (Crustacea, Decapoda) in karibischen Steinkorallen (Madreporaria, Anthozoa). Beitr Palaeontol Österreich 11:35-57

Lobza V, Schieber J (1999) Biogenic sedimentary structures produced by worms in soupy, soft muds: observations from the Chattanooga Shale (Upper Devonian) and experiments. J Sediment Res 69:1041-1049

MacEachern JA, Stelck CR, Pemberton SG (1999) Marine and marginal marine mudstone deposition: paleoenvironmental interpretations based on the integration of ichnology, 
palynology and foraminiferal paleoecology. In: Bergman K (ed) Isolated marine sand bodies: sequence stratigraphic analysis and sedimentological interpretation. Special Publication 64, SEPM, Tulsa, OK

Martin AJ, Rindsburgh AK (2007) Arthropod tracemakers of Nereites? Neoichnological observations of juvenile limulids and their paleoichnological applications. In: Miller W (ed) Trace fossils: concepts, problems, prospects. Elsevier, Amsterdam

Minter NJ, Krainer K, Lucas SG, Braddy SJ, Hunt AP (2007) Palaeoecology of an Early Permian playa lake trace fossil assemblage from Castle Peak, Texas, USA. Palaeogeogr Palaeoclimatol Palaeoecol 246:390-423

Myers AC (1979) Summer and winter burrows of a mantis shrimp, Squilla empusa, in Narragansett Bay, Rhode Island (USA). Estuar Coast Mar Sci 8:87-98

Nara M (1995) Rosselia socialis: a dwelling structure of a probable terebellid polychaete. Lethaia 28:171-178

O'Neill PL (1978) Hydrodynamic analysis of feeding in sand dollars. Oecologia 34:157-174

Pearson NJ, Gingras MK (2006) An ichnological and sedimentological facies model for muddy point-bar deposits. J Sediment Res 76:771-782

Pemberton SG, Frey RW (1985) The Glossifungites ichnofacies: modern examples from the Georgia Coast, USA. In: Curran HA (ed) Biogenic structures: their use in interpreting depositional environments. Special Publication 35, SEPM, Tulsa, OK

Pemberton SG, Risk MJ, Buckley DE (1976) Supershrimp: deep bioturbation in the Strait of Canso, Nova Scotia. Science 192:790-791

Pemberton SG, Frey RW, Walker RG (1984) Probable lobster burrows in the Cardium Formation (Upper Cretaceous) of southern Alberta, Canada, and comments on modern burrowing decapods. J Paleontol 58:1422-1435

Pemberton SG, Spila M, Pulham AJ, Saunders T, MacEachern JA, Robbins D, Sinclair IK (2001) Ichnology and sedimentology of shallow to marginal marine systems: Ben Nevis and Avalon Reservoirs, Jeanne d'Arc Basin. Geological Association of Canada Short Course 15, Geological Association of Canada, St. John's

Rice AL, Chapman CJ (1971) Observations on the burrows and burrowing behavior of two mud-dwelling decapod crustaceans, Nephrops norvegicus and Goneplax rhomboides. Mar Biol 10:330-342

Richards BC (1975) Longusorbis cuniculosus: a new genus and species of Upper Cretaceous crab; with comments on Spray Formation at Shelter Point, Vancouver Island, British Columbia. Can J Earth Sci 12:1850-1863

Richter R (1926) Flachseebeobachtungen zur Paläontologie und Geologie, XII-XIV. Senckenbergiana 8:200-224

Romero-Wetzel MB (1987) Sipunculans as inhabitants of very deep, narrow burrows in deep-sea sediments. Mar Biol 96:87-91

Rona PA, Seilacher A, Luginsland H, Seilacher E and others (2003) Paleodictyon, a living fossil on the deep sea floor. Fall Meeting 2003, American Geophysical Union, Washington, DC, OS32A-0241 (abstract)

Rouse GW, Fauchald K (1998) Recent views on the status, delineation, and classification of the Annelida. Am Zool 38:953-964

Submitted: November 6, 2007; Accepted: April 30, 2008
Saunders TDA, Pemberton SG (1990) On the palaeoecological significance of the trace fossil Macaronichnus. In: Proc Int Sedimentological Congr 13, p 416

Savazzi E (1982) Burrowing habits and cuticular sculptures in Recent sand-dwelling brachyuran decapods from the Northern Adriatic Sea (Mediterranean): Neues Jahrb Geol Palaeontol Abh 163:369-388

Savrda CE, Uddin A (2003) Behavioral variability preserved in Conichnus and Macaronichnus in Upper Cretaceous Tombigbee Sand (Eutaw Formation), central Alabama. In: Proceedings of the Annual Meeting, 35, Geological Society of America, Boulder, CO, p 68 (abstract)

Schäfer W (1956) Wirkungen der Benthos Organismen auf den jungen Schichtverband. Senckenb Lethaea 37:183-263

Schäfer W (1972) Ecology and palaeoecology of marine environments. Oliver and Boyd, Edinburgh

Schieber J (2003) Simple gifts and buried treasures - implications of finding bioturbation and erosion surfaces in black shales. The Sedimentary Record 1:4-9

Seilacher A (1964) Biogenic sedimentary structures. In: Imbrie J, Newell N (eds) Approaches to paleoecology. Wiley, New York

Seilacher A, Seilacher E (1994) Bivalvian trace fossils: a lesson from actuopaleontology. Cour Forschinst Senckenb 169: $5-15$

Shinn EA (1968) Burrowing in recent lime sediments of Florida and the Bahamas. J Paleontol 42:879-894

Stanistreet IG, Le Blanc Smith G, Cadle AB (1980) Trace fossils as sedimentological and palaeoenvironmental indices in the Ecca Group (Lower Permian) of the Transvaal. Trans Geol Soc South Africa 83:333-344

Stevens BA (1929) Ecological observations on Callianassidae of Puget Sound. Ecology 10:399-405

Swinbanks DD (1981) Sediment reworking and the biogenic formation of clay laminae by Abarenicola pacifica. J Sediment Petrol 51:1137-1145

Thayer CW (1983) Sediment-mediated biological disturbance and the evolution of marine benthos. In: Tevesz MJS, McCall PL (eds) Biotic interactions in Recent and fossil benthic communities. Plenum Press, New York

Thompson LD, Pritchard AW (1969) Osmoregulatory capacities of Callianassa and Upogebia (Crustacea: Thalassinidea). Biol Bull 136:114-129

Thurston H (1990) Tidal life; a natural history of the Bay of Fundy. Nimbus Publishing, Halifax

Werner F (2002) Bioturbation structures in marine Holocene sediments of Kiel Bay, western Baltic. Meyniana 54:41-72

Wetzel A (1981) Ökologische und stratigraphische Bedeutung biogener Gefüge in quartären Sedimenten am NW-afrikanischen Kontinentalrand. Meteor ForschungsErgebnisse C 34:1-47

Wetzel A (1991) Ecologic interpretation of deep-sea trace fossil communities. Palaeogeogr Palaeoclimatol Palaeoecol $85: 47-69$

Wetzel A (2002) Modern Nereites in the South China Seaecological association with redox conditions in the sediment. Palaios 17:507-515

Wetzel A (2007) Activities. Ichnology Newsletter 27:35

Wetzel A, Bromley RG (1996) The ichnotaxon Tasselia ordamensis and its junior synonym Caudichnus annulatus. J Paleontol 70:523-526

Proofs received from author(s): June 17, 2008 